\title{
COMET ASSAY IN EVALUATING DNA DAMAGE ASSOCIATED WITH ISCHAEMIA-REPERFUSION INJURY IN PATIENTS UNDERGOING CORONARY SURGERY
}

\author{
Bensu KARAHALIL ${ }^{1}$, Tulin GUMUS ${ }^{2}$, Esra EMERCE ${ }^{1}$, Seval IZDES ${ }^{2}$, \\ Orhan KANBAK ${ }^{2}$ and Elvin $\mathrm{KESIMCI}^{2}$ \\ Gazi University, Faculty of Pharmacy, Toxicology Department ${ }^{1}$, Ataturk Training and Research Hospital, \\ Ministry of Health ${ }^{2}$, Ankara, Turkey \\ Received in December 2008 \\ Accepted in April 2009
}

\begin{abstract}
Ischaemia-reperfusion ( $\mathrm{I} / \mathrm{R})$ injury is responsible for a number of conditions such as coronary bypass and myocardial infarction, and deaths. Oxygen-free radicals formed during I/R have been proposed as the leading causes of tissue injury, and they play an important role in I/R injury. I/R induces oxidative DNA damage (such as purinic and pyrimidinic base lesions). Comet assay is a suitable and sensitive method for early detection of low-level DNA damage. We used modified alkaline comet assay in peripheral blood lymphocytes and evaluated I/R-induced DNA damage in patients undergoing coronary artery bypass graft (CABG) operation (in vivo model for I/R). No statistically significant difference in DNA damage levels was found before surgery, after anaesthesia, ischemia, reperfusion, and surgery. However, blood lactate levels (assessed in parallel with the comet assay) increased after $\mathrm{I} / \mathrm{R}$ and did not return to the baseline level. Our findings showed that $\mathrm{I} / \mathrm{R}$ injury did not induce DNA damage, but increased the lactate levels. This finding suggests that there might be reversible and uncommon necrosis that did not reflect on overall DNA base damage. Further studies are needed using this approach.
\end{abstract}

KEY WORDS: coronary artery bypass graft surgery, DNA lesions, I/R, lactate, reactive oxygen species

Cardiac surgery is associated with a transient postoperative impairment of the myocardial function. Despite considerable effort made to protect the myocardium, the ischemia-reperfusion( $\mathrm{I} / \mathrm{R})$ injury still plays an important role in the morbidity and mortality of patients undergoing coronary artery bypass graft surgery (CABG) (1). During CABG, a blood vessel is removed or redirected from one part of the body and placed around the obstructed part of the coronary artery to bypass it and restore blood flow to the heart muscle. Occlusion of coronary arteries induces myocardial ischaemia followed by myocardial necrosis. Although restoration of blood flow is the only way to save the myocardium from eventual necrosis, reperfusion often exacerbates myocardial damage (2). I/R is one of the main pathophysiological phenomena seen in the anaesthetic practice (organ transplantation, coronary surgery, cardiopulmonary bypass, restoration of blood flow after hypovolaemic shock, etc.), and causes local and systemic inflammatory response (3). Prolonged ischaemia results in a variety of cellular metabolic and ultra structural changes such as decreased adenosine triphosphate (ATP) and glutathione levels. Normally, hypoxanthine is oxidised by xanthine dehydrogenase 
to xanthine. However, during ischaemia, xanthine dehydrogenase is unable to catalyse the conversion of hypoxanthine to xanthine, which then leads to excessive hypoxanthine in the tissue. When oxygen is reintroduced during reperfusion, conversion of the excess hypoxanthine by xanthine oxidase results in the formation of toxic reactive oxygen species (ROS) (4). Leukocytes have been shown to play an important role in the development of tissue injury after I/R. I/R-induced oxygen radical formation causes oxidative DNA strand and plays a significant role in the pathogenesis of reperfusion injury. Although DNA is a well-known target for free radical attack, little attention has been paid to the injury of DNA molecules associated with ischemia and reperfusion (5).

Antioxidant status, some oxidative degradation products and inflammatory mediators have been studied in different $\mathrm{I} / \mathrm{R}$ models so far. One might be able to gain additional knowledge of optimal performance of treatments/procedures involving $\mathrm{I} / \mathrm{R}$. Therefore, the idea in general seems well worth pursuing. Since limited information is available on I/R-induced-DNA damage in the present study, DNA damage induced during CABG operation was measured as increased migration of DNA using the single-cell gel-electrophoresis technique (modified alkaline comet assay). To achieve better sensitivity in the detection of DNA damage, we applied a variation of the modified alkaline comet assay with Fpg and Endo III enzymes. It involves embedding individual cells in agarose on a microscope slide and measuring the degree of migration of nuclear DNA on electrophoresis. The extent of migration is proportional to the number of breaks in DNA, and its evaluation allows indirect measurement of the number of DNA breaks at the single-cell level (6). Beside DNA breaks, we followed hemodynamic and other parameters of oxidative DNA damage in all subjects and analysed whether there was any correlation between these parameters and oxidative DNA damage.

\section{MATERIALS AND METHODS}

\section{Patient population}

Thirty patients ( 19 women and 11 men) aged 30 to 80 years, with American Society of Anesthesiologists (ASA) physical status II and IV, who underwent elective CABG surgery were prospectively studied after obtaining approval from the Ataturk Training and Research Hospital ethics committee. Their demographic data are reported in Table 1. Each patient was informed about the anaesthetic procedure and study protocol in detail at the preoperative visit and gave their written consent before inclusion in the study. Patients answered standardised health questionnaires about their medical history, occupational exposure, and lifestyle such as smoking and drug consumption to rule out confounding effects. We excluded from the study pregnant women and patients receiving hormone treatment, patients with a history of cardiac operation, of neuromuscular disorders, of neurological, haematological, hepatic, renal, or severe pulmonary disease, patients who underwent combined operations (simultaneous valve repair, carotid endarterectomy, or left ventricular aneurysm repair), and patients with a history of drug and alcohol abuse. Before surgery, patients underwent thorough cardiac diagnostics, including determination of ejection fraction. Age, body mass index (BMI), medical history, current medications, preoperative left ventricular ejection fraction (LVEF / \%), and infarction time, if present, were recorded for each patient. All preoperative cardiac medication was continued until the morning of the surgery, except for angiotensin-converting enzyme (ACE) inhibitors. Acetylsalicylic acid and thienopyridine therapy were discontinued one week before operation and replaced by subcutaneous doses of enoxaparin $1 \mathrm{mg} \mathrm{kg}^{-1}$ per day. Sulfonylurea derivates were stopped two days before surgery and replaced by insulin therapy.

\section{Anaesthetic and surgical procedure}

All patients were pre-medicated with oral diazepam $(5 \mathrm{mg})$ the night before and intramuscular morphine sulphate $\left(0.1 \mathrm{mg} \mathrm{kg}^{-1}\right) 45 \mathrm{~min}$ before the surgery. Noninvasive monitoring was established and radial artery cannulated under local anaesthesia. This procedure enables internal monitoring of arterial tension and patient's metabolic and blood-gas status. It was also used to obtain blood samples required for the comet assay. Anaesthesia was similar for all patients, and consisted of $10 \mu \mathrm{g} \mathrm{kg}^{-1}$ fentanyl in combination with $0.3 \mathrm{mg} \mathrm{kg}^{-1}$ etomidat and $0.15 \mathrm{mg} \mathrm{kg}^{-1}$ cisatracurium besylate, given intravenously at induction. Intubation was performed after two minutes and anaesthesia was maintained by additional doses of fentanyl $(5 \mu \mathrm{g}$ $\left.\mathrm{kg}^{-1}\right)$ and cisatracurium besylate $\left(0.03 \mathrm{mg} \mathrm{kg}^{-1}\right)$, and by inhalation of $0.5 \%$ to $2 \%$ sevoflurane. The depth of anaesthesia during surgery was between 40 and 50 , according to the bispectal index (BIS XP'T; 
Aspect Medical Systems, Newton, MA). Patients were receiving air and oxygen (fractional inspired oxygen concentration of $50 \%$ ) throughout the surgery. Ventilation during the anaesthesia was performed in a volume-controlled mode. Respiratory rate and tidal volume were adjusted in the way that normocapnia was achieved. Preparation for surgery, anaesthesia and perioperative vital data monitoring [five-channel ECG, pulse oximetry, capnography, nasopharynx and rectal temperature, arterial blood pressure, and central venous pressure ( $7 \mathrm{~F}$ Arrow, Erdingen, Germany)] were done in the same standardised way for each patient. In surgery, a median sternotomy was made, heparin was given $\left(350 \mathrm{IU} \mathrm{kg}^{-1}\right)$, aortic and right atrial venous cannula were inserted, and a standard cardiopulmonary bypass (CPB) with moderate systemic hypothermia $\left(28{ }^{\circ} \mathrm{C}\right.$ to $30^{\circ} \mathrm{C}$ of nasopharynx temperature) was instituted using a Jostra HL 20 hollow-fibre membrane oxygenator and roller pump generating a nonpulsatile flow. Activated coagulation time (ACT) was kept above 450 s throughout the CPB period. An arterial filter was included in the circuit. Standard pump priming solution was used in each patient. Routine surgical technique and cardioprotective strategies were used in all patients. For myocardial protection, the aorta was cross-clamped and cold anterograde and retrograde intermittent cardioplegia $\left(\mathrm{Plegisol}^{\mathrm{R}}\right.$ Abbott, North Chicago, IL ABD) were used. Left internal mammary artery was used for the left anterior descending coronary artery and saphenous vein for the other coronaries. CPB flow was maintained between $2.2 \mathrm{~L} \mathrm{~min}^{-1} \mathrm{~m}^{-2}$ and $2.5 \mathrm{~L} \mathrm{~min}^{-1} \mathrm{~m}^{-2}$. Mean perfusion pressure was maintained above $60 \mathrm{~mm} \mathrm{Hg}(8 \mathrm{kPa})$ during $\mathrm{CPB}$. Vasopressors and vasodilators were administered as necessary. All distal anastomoses were performed under aortic cross-clamping, while proximal anastomoses were performed with a sitebiting clamp on the ascending aorta. Hematocrit concentrations were maintained between $20 \%$ and $25 \%$. After the surgical procedure, reperfusion of the heart and rewarming to temperature of $36^{\circ} \mathrm{C}$, the heart was placed in atrioventricular mode at a rate of $90 \mathrm{bpm}$, and the patients were separated from CPB. After removal of the aortic cannula, heparin activity was neutralised with protamine at a ratio of $1 \mathrm{mg}$ of protamine per $100 \mathrm{U}$ heparin. Protamine administration was further guided by ACT measurements aiming at $140 \mathrm{~s}$. When mean arterial pressure was below $60 \mathrm{~mm} \mathrm{Hg}$, vasopressor therapy was started. During surgery, we recorded the duration of aortic clamping and $\mathrm{CPB}$, volume of cardioplegic solution used, volume of haemodilution and infusions, diuresis, and minimum body temperature. At the end of the surgical procedure, patients were transferred to the intensive care unit. When haemodynamically stable and rewarmed, the patients were weaned from the ventilator and extubated.

\section{Blood sampling}

Peripheral blood lymphocytes $(\mathrm{V}=2 \mathrm{~mL}$ per patient per time point) were collected in sterile tubes containing heparin. The samples were transported to the laboratory on ice and were processed within $2 \mathrm{~h}$ to $4 \mathrm{~h}$ for modified alkaline comet assay at the following stages of the intervention: the reference level (T1) was obtained immediately after cannulation of the arterial system and before anaesthesia; the second sample (T2) was taken 20 min after anaesthesia was introduced; the third sample (T3) was taken after 20 min of the aortic cross-clamp; the fourth sample (T4) was taken $20 \mathrm{~min}$ after the removal of the aortic cross-clamp; and the final sample (T5) was obtained by venipuncture $24 \mathrm{~h}$ after the surgery.

\section{Study design}

All blood samples were used to evaluate DNA damage with the comet assay. At the same time points, the following serum parameters were determined from blood samples taken from the radial artery: $\mathrm{K}^{+}, \mathrm{Na}^{+}$,

Table 1 Anamnestic data and clinical parameters estimated during cardiac surgery in study patients

\begin{tabular}{lcc}
\hline Parameters & Mean \pm SD & Range \\
\hline Age / years & $59.73 \pm 10.13$ & 36 to 79 \\
BMI / $\mathrm{kg} \mathrm{m}^{-2}$ & $28.96 \pm 4.68$ & 22 to 40 \\
Preoperative ejection fraction $/ \%$ & $50.3 \pm 11.54$ & 31 to 65 \\
Duration of on-pump surgery $/ \mathrm{min}$ & $78.93 \pm 23.47$ & 39 to 132 \\
Duration of cross-clamp (ischaemia) $/ \mathrm{min}$ & $51.6 \pm 14.8$ & 25 to 82 \\
\hline
\end{tabular}

Haematological illness, any transfusion before surgery, endocrine illness, and anaemia were not reported. 
$\mathrm{Ca}^{2+}$, haemoglobin, hematocrit, blood glucose, lactate, and arterial blood-gases. In this study, however, we report only the lactate levels.

\section{Comet assay}

Oxidative DNA damage in peripheral blood lymphocytes was evaluated using a modified alkaline comet assay (8). Lymphocytes isolated from heparinised blood samples were divided into aliquots of $100 \mu \mathrm{L}$, suspended in $100 \mu \mathrm{L}$ of $1 \%$ low melting point agarose at $37^{\circ} \mathrm{C}$, placed on a slide pre-coated with a thin layer of $1 \%$ high melting agarose, and covered with glass cover slips. Two gels were prepared for each sample. Slides were placed at $4{ }^{\circ} \mathrm{C}$ to allow the gel to set, and the cover slips ( $24 \mathrm{~mm} \times 60 \mathrm{~mm}$ ) were then removed. The slides were immersed in lysis solution $\left(2.5 \mathrm{~mol} \mathrm{~L}^{-1} \mathrm{NaCl}, 0.1 \mathrm{~mol} \mathrm{~L}^{-1} \mathrm{Na}_{2}\right.$ EDTA, 10 mmol L ${ }^{-1}$ Tris-HCl, pH 10, $1 \%$ Triton X-100) and stored at $4{ }^{\circ} \mathrm{C}$ overnight. Lysis removes membranes, cytoplasm, and most nuclear proteins, leaving DNA as nucleoids. To measure oxidised bases, the nucleoids were incubated in the gel with $50 \mu \mathrm{L}$ formamidopyrimidine DNA glycosylase (Fpg, specific for altered purines including formamidopyrimidines and 8-oxoGua) or with $50 \mu \mathrm{L}$ endonuclease III (which recognises oxidised pyrimidines), both in a buffer consisting of $40 \mathrm{mmol} \mathrm{L}^{-1} \mathrm{HEPES}, 0.1 \mathrm{~mol}$ $\mathrm{L}^{-1} \mathrm{KCl}, 0.5 \mathrm{mmol} \mathrm{L}^{-1} \mathrm{Na}_{2}$ EDTA, and $0.2 \mathrm{mg} \mathrm{mL}^{-1}$ bovine serum albumin, $\mathrm{pH} 8.0$, or with this buffer alone. Fpg and Endo III were kindly provided by $\mathrm{Dr}$ Andrew Collins, England. These enzymes were used at a final dilution of $1 / 3000$. Gels were covered with a cover slip and incubated at $37^{\circ} \mathrm{C}$ for $30 \mathrm{~min}$ (Fpg) or $45 \mathrm{~min}$ (Endo III and buffer). These enzymes remove the bases, and the resulting abasic sites (apurinic/ apyrimidinic or AP sites) are converted to breaks by an associated AP endonuclease activity. To measure DNA strand breaks, the slides were immersed in $0.3 \mathrm{~mol} \mathrm{~L}^{-1} \mathrm{NaOH}$ and $1 \mathrm{mmol} \mathrm{L}^{-1} \mathrm{Na}_{2}$ EDTA at $4{ }^{\circ} \mathrm{C}$ for $20 \mathrm{~min}$ before electrophoresis at $25 \mathrm{~V}, 300 \mathrm{~mA}$, and ambient temperature of $4{ }^{\circ} \mathrm{C}$ for another $20 \mathrm{~min}$. The slides were removed and immersed in three changes of neutralising buffer $\left[0.4 \mathrm{~mol} \mathrm{~L}^{-1}\right.$ Tris- $\mathrm{HCl}$ (pH 7.5)] at $4{ }^{\circ} \mathrm{C}$ for $5 \mathrm{~min}$. After neutralisation, the gels were stained with $50 \mu \mathrm{L}$ ethidium bromide, and the slides were scored using the Comet Assay III image analysis system (Perceptive Instruments, UK), 50 nuclei per microgel. DNA loops containing breaks extend under electrophoresis to form "comet tails", and the relative intensity of DNA in the tail indicates DNA break frequency. Tail intensity (TI), defined as the percentage of DNA migrated from the head of the comet into the tail, was measured for each nucleus scored.

The levels of lactate were measured using lactate electrodes according to the amperometric measuring principle. Five single measurements were performed at measurements times described above (T1, T2, T3, $\mathrm{T} 4$, and $\mathrm{T} 5$ ).

\section{Statistical analysis}

Data analysis was performed using SPSS for Windows, version 11.5.

The normality of distribution of the continuous variables measured in the comet assay was checked using the Shapiro-Wilks test. Continuous and categorical data were shown as mean \pm standard deviation and percentages, respectively. Normally distributed variables were compared using the Student's $t$-test, whereas abnormally distributed data were compared using the Mann-Whitney U test. The differences between repeated measures were evaluated by Repeated Measures ANOVA or the Friedman test, where appropriate. When the p-value tested by the Friedman test was significant, we used the multiple comparison test to identify which measurement differed from which. The degree of association between continuous variables was calculated using the Pearson's correlation coefficient. The Bonferroni correction was applied for all possible pairwise and within-group comparisons.

Differences between repeated lactate levels were evaluated using the Friedman test. Again we used multiple comparison test to identify which measurement differed from which, where applicable.

A p-value of less than 0.05 was considered statistically significant.

\section{RESULTS}

During coronary bypass surgery and intensive care, none of the patients had any signs of myocardial infarction or ischaemia on the electrocardiogram. Tables 2 and 3 show the results obtained with the modified alkaline comet assay performed with the buffer, endonuclease III, or Fpg enzymes. The usual practice in measuring oxidative DNA damage with Fpg and Endo III enzymes is to incubate a slide (two 
gels) with buffer alone and another slide with buffer plus enzyme, and to subtract the mean comet score of the control (buffer) slide from the mean score of the buffer plus enzyme slide. Normally, there is a small number of background strand breaks, but incubation with enzymes reveals sensitive sites in DNA which are indicators of oxidised bases.

Samples incubated with enzymes showed no significant increase in single-strand breaks compared to samples incubated with buffer alone. No inter-group (T1-T5) differences were found with respect to the time course of DNA damage. Purine base damage slightly increased between T2 [(2.47 \pm 4.11$) \%$ DNA in the tail $]$ and T3 [(2.84 \pm 4.74$) \%$ DNA in the tail $]$ in the comet assay regardless of the enzyme used, but it was not statistically significant (Table 2). No changes in the comet assay with buffer were detected (Table 2).
We also investigated a possible modifying effect of smoking on DNA damage measured in time periods T1 to T5 (Table 3) and found no statistically significant increase in smokers over non-smokers, which suggests that smoking had no synergistic effect on I/R-induced DNA damage.

\section{Serum lactate levels}

Figure 1 shows serum lactate levels measured in blood samples taken before, during, and after surgery. No difference was observed between lactate levels in T1 (before surgery) and T2 (after anaesthesia). However, the lactate levels started to increase significantly during ischaemia $(\mathrm{p}<0.001$; Friedman multiple comparison test) compared to T2. They kept rising until reperfusion. At final measurement $24 \mathrm{~h}$

Table 2 DNA damage in peripheral blood lymphocytes of cardiac patients estimated using the comet assay at five different points in time (T1 to T5). Mean values $\pm S D$ are reported.

\begin{tabular}{lccc}
\hline Sample & \multicolumn{3}{c}{ DNA in the tail / \% } \\
\cline { 2 - 4 } & Single strand breaks & Endo III-sensitive sites & Fpg-sensitive sites \\
\hline Before surgery (T1) & $8.23 \pm 3.35$ & $2.12 \pm 3.43$ & $1.9 \pm 4.10$ \\
After anaesthesia (T2) & $8.32 \pm 3.51$ & $1.74 \pm 3.76$ & $2.47 \pm 4.11$ \\
After ischaemia (T3) & $7.79 \pm 3.28$ & $2.94 \pm 3.61$ & $2.84 \pm 4.74$ \\
After reperfusion (T4) & $8.26 \pm 3.08$ & $1.39 \pm 3.24$ & $1.96 \pm 4.63$ \\
After surgery (T5) & $7.79 \pm 2.19$ & $1.88 \pm 3.57$ & $1.27 \pm 3.29$ \\
\hline
\end{tabular}

*Intra-group comparisons were performed by Friedman test, but no significant differences were observed.

Table 3 The impact of smoking on DNA damage in peripheral blood lymphocytes of cardiac patients. Blood sampling was performed at five different points in time (T1 to T5). Mean values $\pm S D$ are reported.

\begin{tabular}{lccc}
\hline Sample & \multicolumn{3}{c}{ DNA in the comet tail / \% } \\
\cline { 2 - 4 } & Single strand breaks & Endo III-sensitive sites & Fpg-sensitive sites \\
\hline Before surgery (T1) & $7.81 \pm 3.99$ & $1.34 \pm 2.97$ & $1.82 \pm 4.65$ \\
Smokers (n=13) & $8.54 \pm 2.87$ & $2.72 \pm 3.71$ & $1.95 \pm 3.77$ \\
Non-smokers (n=17) & & & \\
\hline After anaesthesia (T2) & $7.32 \pm 4.50$ & $2.33 \pm 4.28$ & $3.03 \pm 4.85$ \\
Smokers & $9.08 \pm 2.40$ & $1.28 \pm 3.37$ & $2.05 \pm 3.58$ \\
Non-smokers & & & \\
\hline After ischaemia (T3) & $6.43 \pm 2.89$ & $2.68 \pm 3.09$ & $3.35 \pm 4.96$ \\
Smokers & $8.83 \pm 3.25$ & $3.14 \pm 4.04$ & $2.45 \pm 0.68$ \\
Non-smokers & & & \\
After reperfusion (T4) & $7.97 \pm 4.16$ & $0.84 \pm 3.18$ & $0.71 \pm 4.28$ \\
Smokers & $8.49 \pm 2.04$ & $1.82 \pm 3.32$ & $2.92 \pm 4.78$ \\
Non-smokers & & & \\
\hline After surgery (T5) & $6.79 \pm 1.77$ & $2.13 \pm 3.2$ & $1.77 \pm 2.44$ \\
Smokers & $8.56 \pm 2.22$ & $1.69 \pm 3.91$ & $0.90 \pm 3.85$ \\
Non-smokers &
\end{tabular}

* Intra-group comparisons were performed by Friedman test and intergroup comparisons were performed by Mann Whitney

U Test; no significant differences were observed. 


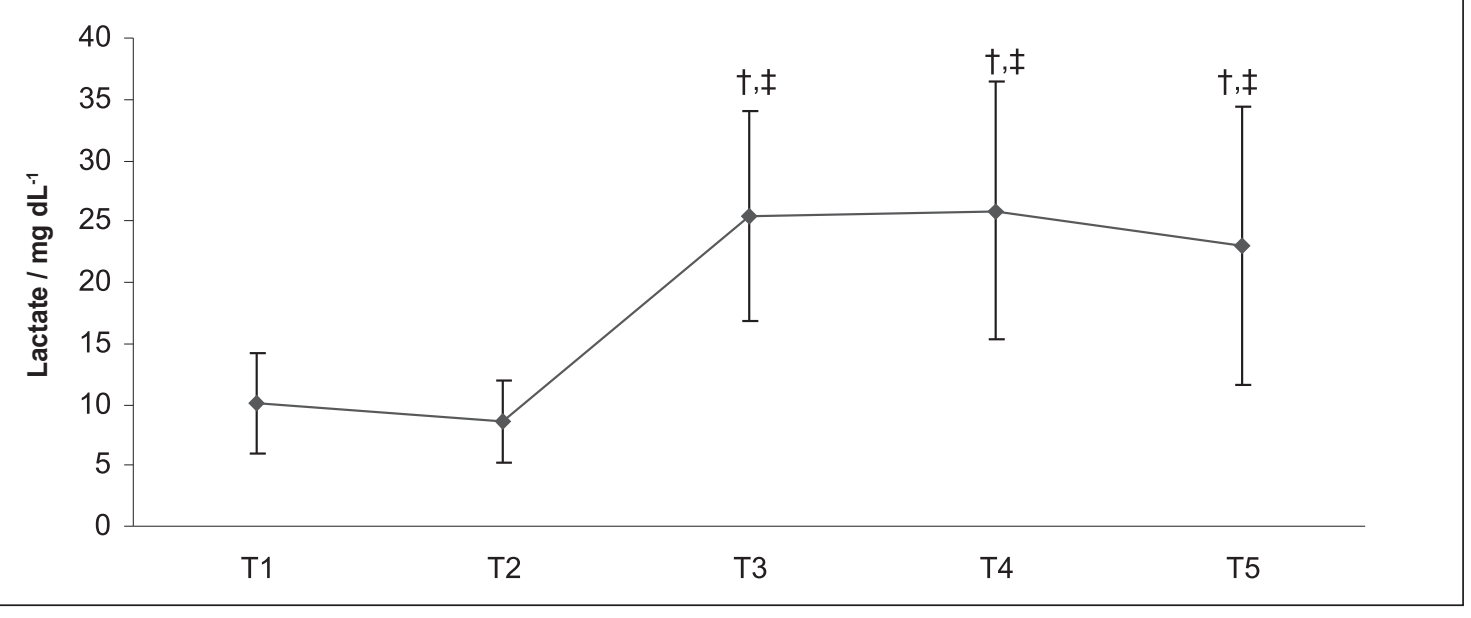

Figure 1 Serum lactate levels (mean $\pm S D$ ) measured at five different points in time (T1 to T5) in patients undergoing coronary surgery

T1-Before Surgery; T2- 20 min after anaesthesia; T3- 20 min after ischaemia; T4- 20 min after reperfusion; T5- 24 $h$ after surgery

+ Statistically significant compared to $T 1(p<0.001)$, $\neq$ statistically significant compared to T2 $(p<0.001) ;$ Friedman multiple comparison test

after the surgery they dropped slightly, but did not return to $\mathrm{T} 1$ and $\mathrm{T} 2$ values.

We also evaluated hemodynamic and other blood/ serum parameters, but no significant correlation or any changes were observed (data not shown).

\section{DISCUSSION}

Our study deals with a potentially very interesting subject, especially for personnel who provide health care for cardiac patients. As it is impossible to take a sample from the myocardium of cardiac patients to investigate DNA damage, in designing this investigation we took advantage of previously published studies on patients undergoing coronary surgery (7-12). In these studies, plasma or whole blood samples were used and DNA damage assessed using the comet assay, or the activity of antioxidant enzyme or metabolite levels were measured. This means that blood or blood cells may be affected in the same manner as the myocardium and might reflect tissue damage.

The role of oxidative stress in tissue damage caused by $I / R$ has been described by many. $I / R$ of an organ or tissue results in cellular injury, triggering a complex series of biochemical events. Free radical species are believed to be bring the most harm to organs upon reperfusion. However, definitive evidence of their causative role is often missing due to limited methods to assess oxidative stress in vivo (13). Many studies indicate that ROS formation after I/R may initiate the cascade of cellular injury (15). A variety of experimental models of ischaemic injury have also shown that free radicals induce post-ischaemic oxidative damage to DNA (16-19). An optimal therapeutic strategy is to prevent and neutralise ROS formation (14). Izdes et al. (19) investigated the relative effects of general and regional anaesthesia on oxidative variables in patients who had a pneumatic tourniquet for lower limb surgery (an in vivo model for $\mathrm{I} / \mathrm{R}$ ) and did not find any significant differences in superoxide dismutase (SOD) activity between the groups. What they found in general anaesthesia was a significantly lower concentration of malondialdehyde (MDA), lipid hydroperoxide (LHP), and nitrite/nitrate ratio (NOx) (19). Our findings on the genotoxicity of sevoflurane are in accordance with Szyfter et al. (20), who investigated genotoxicity of sevoflurane in vivo and in vitro using the comet assay and whose findings suggested that sevoflurane did not have genotoxic properties. In contrast, some studies showed that sevoflurane induced DNA migration, but sevoflurane was either used in combination with other anaesthetic agents or DNA damage was detected $60 \mathrm{~min}$ to 180 min after anaesthesia $(21,22)$. In our study, we used sevoflurane alone and not in combination and detected DNA damage 20 min after anaesthesia. Nagayoshi et 
al. (23) assessed serial changes in oxidative stress in patients with acute myocardial infarction by measuring urinary $8-\mathrm{OHdG}$ excretion. They found that the levels of 8 -OHdG were higher in cardiac patients than in non-cardiac patients. In our study, we used Endo III to detect oxidised pyrimidines and Fpg to detect 8oxoguanine as the major purine oxidation product, as well as other altered purines.

Willy et al. (24) examined the adverse effects of tourniquet ischaemia on DNA in peripheral blood leukocytes using the comet assay, and found significantly increased DNA migration. I/R causes chemotactic accumulation, and activation and interaction of all circulating leukocytes with the endothelium. Furthermore, several studies have pointed to a release of substantial amounts of oxygen radicals and other reactive agents from these cells (25). In our study, we found a slight but not statistically significant increase in DNA damage that may be associated with oxygen radicals formed after ischaemia. Our results differ from Willy et al. (24), as the duration of ischemia was shorter (25 min). We assumed that DNA damage was not induced at this point. Hauser et al. (8) investigated DNA damage from possible $\mathrm{I} / \mathrm{R}$ injury during porcine thoracic aortic cross-clamping in eighteen domestic pigs. They did not find inter-group differences in comet assay parameters assessed both in vivo in whole blood before surgery, before clamping, before declamping, $2 \mathrm{~h}$ after declamping, and ex vivo in isolated lymphocytes, sampled immediately before clamping and analysed before, immediately after, and $1 \mathrm{~h}$ and $2 \mathrm{~h}$ after exposure to 4 bar $100 \%$ $\mathrm{O}_{2}$ for $2 \mathrm{~h}$. Our results are similar to Hauser et al. (7). We did not find any differences in DNA damage between sampling times. We assumed that active repair of endogenous oxidative DNA lesions took place in the myocardium, which survived the insults of ischaemia and reperfusion. We further believe that repair of oxidative base lesions in the myocardium was associated with induced repair activity, which is attributed to the over expression and activation of some repair enzymes, especially 8-oxoguanine DNA glycosylase (OGG1).

In ischaemia, the myocardial metabolic status determines the expansion of necrosis. Decreased ATP levels and increased lactate content in ischaemic myocardium undergoing lethal injury are known to be related to the expansion of irreversible damage. However, their individual contributions have not yet been firmly established (25). Higher production of lactate in anaerobic conditions requires greater availability of glucose, which in part depends on glucagon metabolism. Lactate is recognised as a "central player in cellular, regional and whole body metabolism" (26). Thus, greater lactate production may be related to a preservation of the function of the $\mathrm{Na}^{+}-\mathrm{K}^{+}$-ATPase pump, because it can use glycolytic ATP. During ischaemia, the glycolytic pathway is upregulated anaerobically to produce ATP. However, this is short-lived due to negative feedback on phosphofructokinase from accumulating lactate (27). Guth et al. (28) demonstrated a close inverse relationship between regional myocardial lactate release and regional subendocardial blood flow during graded ischaemia. We also found a significant increase in the lactate levels in T3 and T4 periods. $\mathrm{I} / \mathrm{R}$ did not induce DNA damage, but it did increase lactate levels.

\section{CONCLUSIONS}

Considering the association between DNA damage and oxidative response to $I / R$, it remains unclear why we did not observe a significant increase in DNA strand breaks and purine and pyrimidine base damages after I/R. The duration of I/R during CABG operation is shorter than in animal experiments and in vitro tests. Our study group directly reflects clinical practice, and not experimental ones. It was therefore impossible to administer extreme doses. Our data show that I/R-related tissue injury did not increase endogenous DNA damage. Higher lactate levels may be responsible for reversible and small necrosis. Our study furthers the understanding of the mechanism of I/R-induced injury. Under clinical circumstances, the comet assay has not been useful, since there might not be enough DNA damage induced by I/R to be detected by this method.

\section{Acknowledgement}

The authors are grateful to L'OREAL Turkey for the "Woman in Science Fellowship Award" and generous financial support.

\section{REFERENCES}

1. Taşkıran A, Eskiocak S, Ege T, Duran E, Gülen S. Koroner bypass operasyonunda miyokard doku hasarının ve oksidan stresin araştırılması [Investigation of myocardial tissue injury and oxidant stress during coronary bypass, in Turk]. Turk J Biochem 2004;29:193-8. 
2. Ozer MK, Parlakpınar H, Acet A. Reduction of ischemiareperfusion induced myocardial infarct size in rats by caffeic acid phenethyl ester (CAPE). Clin Biochem 2004;37:7025.

3. Piper HM, Meuter K, Schäfer C. Cellular mechanisms of ischemia-reperfusion injury. Ann Thorac Surg 2003;75: S644-8.

4. Collard CD, Gelman S. Pathophysiology, clinical manifestations, and prevention of ischemia-reperfusion injury. Anesthesiology 2001;94:1133-8.

5. Cordis GA, Maulik G, Bagchi D, Riedel W, Das DK Detection of oxidative DNA damage to ischemic reperfused rat hearts by 8-hydroxydeoxyguanosine formation. J Mol Cell Cardiol 1998;30:1939-44.

6. Giovannelli L, Cozzi A, Guarnieri I, Dolara P, Moroni F. Comet assay as a novel approach for studying DNA damage in focal cerebral ischemia: differential effects of NMDA receptor antagonists and poly(ADP-ribose) polymerase inhibitors. J Cereb Blood Flow Metab 2002;22:697-704.

7. Hauser B, Gröger M, Ehrmann U, Albicini M, Brückner UB, Schelzig H, Venkatesh B, Li H, Szabó C, Speit G, Radermacher P, Kick J. The parp-1 inhibitor ino-1001 facilitates hemodynamic stabilization without affecting DNA repair in porcine thoracic aortic cross-clamping-induce breakage ischemia/reperfusion. Shock 2006;25:633-40.

8. Alleva R, Tomasetti M, Solenghi MD, Stagni F, Gamberini F, Bassi A, Fornasari PM, Fanelli G, Borghi B. Lymphocyte DNA damage precedes DNA repair or cell death after orthopaedic surgery under general anaesthesia. Mutagenesis 2003;18:423-8

9. Karabiyik L, Sardaş S, Polat U, KocabaS NA, Karakaya AE. Comparison of genotoxicity of sevoflurane and isoflurane in human lymphocytes studied in vivo using the comet assay. Mutat Res 2001;492:99-107.

10. Oshida K, Iwanaga E, Miyamoto-Kuramitsu K, Miyamoto YJ. An in vivo comet assay of multiple organs (liver, kidney and bone marrow) in mice treated with methyl methanesulfonate and acetaminophen accompanied by hematology and/or blood chemistry. J Toxicol Sci 2008;33:515-24

11. Pincheira J, Carrera P, Marcelain K, De La Torre C. Hepatocytes, rather than leukocytes reverse DNA damage in vivo induced by whole body gamma- irradiation of mice, as shown by the alkaline comet assay. Biol Res 2008;41:21725 .

12. Collins A. The comet assay for DNA damage and repair: principles, applications, and limitations. Mol Biotechnol 2004;26:249-61

13. Favreau F, Petit-Paris I, Hauet T, Dutheil D, Papet Y, Mauco $\mathrm{G}$, Tallineau C. Cyclooxygenase 1-dependent production of F2-isoprostane and changes in redox status during warm renal ischemia-reperfusion. Free Rad Biol Med 2004;36:103442.

14. Chen H, Xing B, Liu X, Zhan B, Zhou J, Zhu H, Chen Z. Similarities between ozone oxidative preconditioning and ischemic preconditioning in renal ischemia/reperfusion injury. Arch Med Res 2008;39:169-78.
15. Maulik G, Cordis GA, Das DK. Oxidative damage to myocardial proteins and DNA during ischemia and reperfusion. Ann NY Acad Sci 1996;793:431-6.

16. Tobita M, Nagano I, Nakamura S, Itoyama Y, Kogure K. DNA single-strand breaks in postischemic gerbil brain detected by in situ nick translation procedure. Neurosci Lett 1995;200:129-32.

17. Chen J, Jin K, Chen M, Pei W, Kawaguchi K, Greenberg DA, Simon RP. Early detection of DNA strand breaks in the brain after transient focal ischemia: implications for the role of DNA damage in apoptosis and neuronal cell death. J Neurochem 1997;69:232-45.

18. Loft S, Larsen PN, Rasmussen A, Fischer NA, Bondesen S, Kirkegaard P, Rasmussen LS, Ejlersen E, Tornøe K, Bergholdt R. Oxidative DNA damage after transplantation of the liver and small intestine in pigs. Transplantation 1995;59:16-20

19. Izdes S, Sepici-Dincel A, Gozdemir M, Ozkan Y, Kanbak O. The effect of general and regional anesthesia on ischemiareperfusion injury. Anaesth Intensive Care 2007;35:451-2.

20. Szyfter K, Szulc R, Mikstacki A, Stachecki I, Rydzanicz M, Jałoszyński P. Genotoxicity of inhalation anaesthetics: DNA lesions generated by sevoflurane in vitro and in vivo. J Appl Gen 2004;45:369-74.

21. Reitz M, Antonini-Rumpf E, Lanz E. DNA single strand breaks in peripheral human lymphocytes after anesthesia with isoflurane-nitrous oxide-oxygen. Arzneimittelforschung 1993;3:1258-61.

22. Sardaş S, Karabiyik L, Aygün N, Karakaya AE. DNA damage evaluated by the alkaline comet assay in lymphocytes of humans anaesthetized with isoflurane. Mutat Res 1998;418:16.

23. Nagayoshi N, Kawano H, Hokamaki J, Miyamoto S, Kojima S, Shimomura H, Tsujita K, Sakamoto T, Yoshimura M, Ogawa H. Urinary 8-hydroxy-2'-deoxyguanosine levels increase after reperfusion in acute myocardial infarction and may predict subsequent cardiac events. Am J Cardiol 2005;95:514-7.

24. Willy C, Dahouk S, Starck C, Kaffenberger W, Gerngrob H, Plappert UG. DNA damage in human leukocytes after ischemia/reperfusion injury. Free Rad Biol Med 2000;28:112.

25. Vogt AM, Ackermann C, Yildiz M, Schoels W, Kübler W. Lactate accumulation rather than ATP depletion predicts ischemic myocardial necrosis: implications for the development of lethal myocardial injury. Biochim Biophys Acta 2002;1586:219-26.

26. Gladden LB. Lactate metabolism: a new paradigm for the third millennium. J Physiol 2004;558:5-30.

27. Gal J, Riedel B, Kertai MD, Jancso G, Acsady G, Royston D, Roth E. Effects of fructose-1,6-diphosphate on endo- and myocardial purine metabolism during coronary artery bypass grafting surgery. J Cardiovasc Surg 2007;48:751-6.

28. Guth BD, Wisneski JA, Neese RA, White FC, Heusch G, Mazer CD, Gertz EW. Myocardial lactate release during ischemia in swine. Relation to regional blood flow. Circulation 1990;81:1948-58. 


\title{
Sažetak
}

\section{PRIMJENA KOMETNOG TESTA U PROCJENI OŠTEĆENJA DNA NASTALIH ZBOG ISHEMIJSKO- REPERFUZIJSKIH OZLJEDA U BOLESNIKA PODVRGNUTIH KIRURŠKIM ZAHVATIMA NA KORONARNIM ŽILAMA}

\begin{abstract}
Ishemijsko-reperfuzijska (I/R) ozljeda čest je uzročnik pobola i smrtnosti u slučajevima kao što su ugradnja koronarnih premosnica, infarkt miokarda i sl. Slobodni kisikovi radikali koji nastaju tijekom procesa ishemije i reperfuzije smatraju se jednim od glavnih uzročnika oštećenja tkiva i imaju važnu ulogu u I/R ozljedama. I/R ozljede izazivaju oksidativna oštećenja u DNA (primjerice oštećenja purinskih i pirimidinskih baza). Kometni test osjetljiva je metoda koja omogućuje utvrđivanje niskih razina primarnih oštećenja u molekuli DNA. U ovom smo istraživanju primjenom kometnog testa na bijelim krvnim stanicama procjenjivali razine oštećenja u DNA nastale zbog I/R ozljeda u bolesnika podvrgnutih ugradnji premosnice koronarne arterije (in vivo model za I/R). Rezultati istraživanja upućuju na to da nema značajnih razlika u razinama oštećenja DNA izmjerenim u uzorcima krvi uzimanima prije kirurškog zahvata, nakon anestezije te tijekom ishemije, reperfuzije i zahvata. Međutim, uočeno je da su nakon I/R ozljede porasle razine laktata u serumu koje se više nisu vratile na početne vrijednosti. Takve vrijednosti laktata u serumu upućuju na to da tijekom I/R nastupa neobična i reverzibilna nekroza koja se, međutim, ne odražava na stupanj oštećenja DNA. Za objašnjenje ovih zapažanja potrebna su daljnja istraživanja.
\end{abstract}

KLJUČNE RIJEČI: I/R, koronarne arterije, razine laktata u serumu, reaktivni kisikovi radikali, ugradnja premosnice

\section{CORRESPONDING AUTHOR:}

Professor Bensu Karahalil, PhD

Gazi University, Faculty of Pharmacy,

Toxicology Department

06330, Hipodrom, Ankara, Turkey.

E-mail:bensuka@gmail.com 